\title{
Which profitability Measures Explain Better the Bank's Financial Soundness?
}

\author{
Melita Charitou* \\ University of Nicosia, Cyprus \\ *Corresponding author: charitou.m@unic.ac.cy \\ Received January 10, 2019; Revised February 17, 2019; Accepted April 10, 2019
}

\begin{abstract}
The aim of this study is to examine the profitability measures that affect the bank's financial soundness, as measured by capital adequacy. Using a dataset of 2445 bank-year observations, results show that three profitability measures increase the variability of the capital adequacy ratios by $14.40 \%$. Specifically, results show that return on assets, net interest margin and losses affect substantially bank's financial health. The results of this study are expected to aid bank executives, bank regulators and other stakeholders in evaluating better the bank's financial soundness.
\end{abstract}

Keywords: profitability, financial institutions, capital adequacy ratios, Basel Accord

Cite This Article: Melita Charitou, "Which profitability Measures Explain Better the Bank's Financial Soundness?” Journal of Finance and Economics, vol. 7, no. 2 (2019): 62-67. doi: 10.12691/jfe-7-2-3.

\section{Introduction}

Financial institutions in recent years have been facing higher risks of insolvency. The fact that banks are highly leveraged, it makes it even more difficult to survive if their reserves become inadequate to meet the debt holders needs. In an attempt to stabilize the financial sector and protect depositors, regulatory bodies worldwide, including the Bank of International Settlements (BIS), require that financial institutions maintain adequate capital, measured in the form of capital adequacy ratio (CAR), [1]. These ratios aim to promote stability and protect depositors of financial institutions $[2,3,4,5]$.

Since capital adequacy is considered of paramount importance for the bank's financial soundness, researchers examined the determinants of the CARs, among those profitability, with inconclusive results. Mili, Sahut, and Trimeche [6], provided evidence that profitability and risk variables play an important role in explaining CARs, whereas other profitability ratios, including return on assets are not statistically significant in explaining CARs. In contrast to the above study, Aktas et al. [7] showed that return on assets, a measure of profitability, relates positively to CARs. In contrast to the above studies, Ahmad, Ariff, and Skully [8] provided evidence that the profitability measure net interest margin has a negative effect on CARs, a result inconsistent to expectations.

In an attempt to provide further evidence on the effect of profitability on CARs, we use all U.S. financial institutions included in the Federal Depositary Insurance Corporation database. The present study complements and extends prior studies in the following respects: We test simultaneously several profitability measures. We also use a much larger and more recent dataset of financial institutions. The data used in the present study were obtained from FDIC database and covered the period 2012 - 2017. The total number of firm year observations were 2,445. Multivariate statistical analysis results show that financial institutions with greater return on assets are expected to have higher capital adequacy, whereas banks with losses and higher net interest margins are expected to have lower capital adequacy. So firms that have losses are expected to contribution negatively towards bank's capital adequacy. The same applies for banks with very high net interest margins, meaning that these banks take much higher risk. Evidence shows that when the profitability measures are excluded from the model, the model's Rsquared is $16.10 \%$ whereas when the three profitability variables are added in the model, the model's R-squared increases to $30.50 \%$, which is an overall improvement of $14.10 \%$.

The study proceeds as follows. Section two provides review of the literature. In section 3 we discuss data selection and the research design. Critical analysis of statistical results are presented in section 5 and the last section provides summary and conclusions.

\section{Background and Motivation}

Financial institutions play a very important role in the economy due to the fact that they have as deposits the savings of the entire economy. If financial institutions face financial distress problems, the whole economy will suffer since depositors will lose their savings and at the same time the governments have to step in and pay the deposit insurance $[9,10]$. Regulatory bodies worldwide, among those the Bank for International Settlements, through the Basel Accords, tried to impose some mechanisms, such as minimum capital requirements, namely the so called 
capital adequacy ratios (CAR). CARs are used to promote the stability and efficiency of financial systems worldwide $[11,12]$. Also, CARs are used to protect stakeholders, and especially depositors, as a result of major risks faced by banks, especially, credit risk (from both balance sheet and off balance sheet exposures), operational risk, market risk and liquidity risk $[1,3,4]$.

Since CARs relate to the bank's financial soundness, several researchers examined empirically the determinants of CARs, using various explanatory variables, among those, efficiency, riskiness, profitability and bank size. Evidence though on the relationship between profitability and CARs has been inconclusive.

Using multinational financial institutions, Mili et al. [6], showed that profitability and riskiness, as measured by net interest margin and loan loss provisions, respectively, are positively related to CARs. On the other hand, ROA, another profitability variable, was shown to be statistically insignificant. Consistent with the initial results of Mili et al [6], Bateni et. al. [13], Bokhari et. al. [14], Ho and Hsu [15], and showed that there exists a positive relationship between profitability and CARs. Also a study by Aktas et al. [7], who used a dataset of European banks during the crisis period provided evidence that profitability as measured by ROA relates to CARs. In contract to the above results, the following researchers found negative, not positive relationship with CARS. Specifically, Ahmad, Ariff, and Skully [8] provided evidence that the profitability measure net interest margin is negatively related to CARs. These results are in contrast to prior studies possibly because banks with high interest margins undertake higher risk, and subsequently these banks have lower asset quality and thus higher non performing loans. In contrast to the aforementioned studies, Sivaraman, Krishnan and Sukar [16] who tested the determinants of CARS of U.S. CARs, provided evidence that bank profitability, riskiness and liquidity do not explain CARs. Consistent with Sivaraman et al [16], Shingjergji and Hyseni [17] showed that profitability is not stuatistically significant in explaining CARs.

Thus, as it can be seen from extant literature, the evidence regarding the relationship between profitability and CARS is mixed and inconclusive. Our study differs from prior studies in the following respects: We test simultaneously several profitability measures by using a much larger and more recent dataset of financial institutions.

The following hypothesis will be examined:

H1: There exists a positive relationship between various profitability measures and Capital Adequacy Ratios (CARs).

\section{Methodology}

\subsection{Collection of Data}

The data used in this study were collected from FDIC (Federal Deposit Insurance Corporation) database. FDIC is a US federal agency that insures bank deposits in case a financial institution faces financial distress problems. Our final sample size consists of 2,445 bank year observations from all US National Commercial banks in FDIC for the period 2012-2017. In order to be consistent with extant studies, we excluded from our sample observations with absolute studentized residuals greater than 2 since they were considered outliers.

\subsection{Multivariate Models}

The following multivariate regression models will be used to examine the factors that affect the capital adequacy ratios of the US national financial institutions:

Reduced Model without profitability measures:

$$
\begin{aligned}
C A R_{\text {Tier } 1}= & c_{0}+c_{4} * \text { ch }_{\text {off }} \text { prov } \\
& +c_{5} * \text { Prov }_{\text {Loans }} * \text { ch }_{\text {offloans }} c_{7} * \text { Loans }_{\text {dep }}+c_{8} * \text { IntExp } \\
& +c_{9} * \text { ROE }+c_{10} * \text { LnTA }+e .
\end{aligned}
$$

Full Model with all profitability measures:

$$
\begin{aligned}
\text { CAR }_{\text {Tier } 1}= & c_{0}+c_{1} * \text { ROA }+c_{2} * \text { Nimy }+c_{3} * \text { Loss } \\
& +c_{4} * \text { ch }_{\text {off }} \text { prov } \\
& +c_{5} * \text { Prov }_{\text {Loans }} \\
& +c_{6} * \text { ch }_{\text {offloans }} c_{7} * \text { Loans }_{\text {dep }}+c_{8} * \text { IntExp }_{T A} \\
& +c_{9} * \text { ROE }+c_{10} * \text { LnTA }+e .
\end{aligned}
$$

The dependent variable is CAR_Tier1: capital adequacy ratio-Tier1. Independent variables are: ROA: Return on assets, Nimy: net interest margin, Loss is an indicator variable that takes the value of 1 if the financial institution has losses during a specific year and 0 otherwise, charge_off_Prov is the credit loss provision to net charge off, Prov_Loans: loss allowance to loans, Loans_Dep: net loans and leases to deposits, IntExp_TA is the interest expense to total assets, ROE is the return on equity, LnTA is the natural logarithm of total assets. $\mathrm{C}_{0}$ is the intercept term, $\mathrm{c}_{\mathrm{i}}$ : slope coefficient, $\mathrm{e}_{\mathrm{i}}$ : error term.

\section{Empirical Results}

\subsection{Descriptive Statistics}

In Table 1 we show descriptive statistics for our variables that we included in our comprehensive multivariate regression model. Our results show that US banks have on average Tier 1 Capital adequacy ratios 15\% (median 13.1\%). The means of the three profitability ratios, Return on Assets (ROA), net interest margin (nimy) and loss are $1.2 \%, 4 \%$ and $3.4 \%$, respectively. The means of the ch_off_prov and ch_off_loans are 0.271 and 0.474 , respectively. Regarding Prov_loans, Loans_Dep, intExp_TA and ROE, their means are 1.535, 3,686, 0.5\% and $9.4 \%$, respectively.

\subsection{Correlation Analysis}

Results in Table 2 show Pearson correlation analysis results between CARs, our independent variable, and all the independent variables. Evidence presented indicates that there is a relationship between Capital Adequacy Ratios (CAR_Tier1) and profitability ratios and other explanatory variables. Results show that the return on 
assets and net interest margin are positively related to capital adequacy whereas losses are negatively related. Specifically, the correlation between ROA and capital adequacy is $39.3 \%$ and the correlation between net interest margin and capital adequacy is $2.2 \%$. Evidence also shows that ch_off_prov, provisions to loans and ch_off_loans variables are positively related to capital adequacy of financial institutions. Furthermore, results show that there is no multicollinearity between the explanatory variables since the the highest correlation among the these variables is only $63.4 \%$. Detailed information about multicollinearity testing is presented later on in this study when the full regression analysis model is discussed.

\subsection{Multivariate Analysis Results}

\subsubsection{Reduced Model}

In Table 3 we present results on the relationship between financial variables (excluding profitability) and capital adequacy (CAR_Tier1), for all US banks from 2012 till 2017. Our final dataset includes 2,445 bank-year observations.

Regression model used:

$$
\begin{aligned}
\text { CAR }_{\text {Tier } 1}= & c_{0}+c_{4} * \text { ch }_{\text {off prov }}+c_{5} * \text { Prov }_{\text {Loans }} \\
& +c_{6} * \text { ch }_{\text {off loans }} c_{7} * \text { Loans }_{\text {dep }}+c_{8} * \operatorname{IntExp}_{\text {TA }} \\
& +c_{9} * \text { ROE }+c_{10} * \text { LnTA }+e .
\end{aligned}
$$

Table 1.

\begin{tabular}{lccc}
\hline & $\mathrm{N}$ & Mean & Median \\
\hline CAR_Tier1 & 2445 & 0.150 & 0.131 \\
ROA & 2445 & 0.012 & 0.010 \\
Nimy & 2445 & 0.040 & 0.035 \\
LOSS & 2445 & 0.034 & 0.000 \\
Ch_off_prov & 2445 & 0.271 & 0.097 \\
Prov_Loans & 2445 & 1.535 & 0.021 \\
Ch_off_Loans & 2445 & 0.474 & 0.227 \\
Loans_Dep & 2445 & 3.686 & 0.176 \\
IntExp_TA & 2445 & 0.005 & 0.846 \\
ROE & 2445 & 0.094 & 0.004 \\
LnTA & 2445 & 15.069 & 0.959 \\
\hline
\end{tabular}

Descriptive statistics results for all our U.S. banks included in our dataset for the period 2012-2017 are presented in this table. The dependent variable is CAR_Tier1: capital adequacy ratio-Tier 1. Independent variables are: Return on assets, Nimy: net interest margin, Loss is an indicator variable that takes the value of 1 if the financial institution has losses during a specific year and 0 otherwise, charge_off_Prov is the credit loss provision to net charge off, Prov_Loans: loss allowance to loans, charge_off_loans: net charge off to loans, Loans_Dep: net loans and leases to deposits, IntExp_TA is

\begin{tabular}{|c|c|c|c|c|c|c|c|}
\hline & CAR_Tier1 & ROA & Nimy & LOSS & Ch_off_prov & Prov_Loans & Ch_off_Loans \\
\hline CAR_Tier1 & 1.000 & .393 & .022 & -.040 & .035 & .280 & .110 \\
\hline ROA & & 1.000 & .358 & -.243 & .019 & .153 & .160 \\
\hline Nimy & & & 1.000 & -.046 & -.025 & .437 & .634 \\
\hline LOSS & & & & 1.000 & .015 & .179 & .194 \\
\hline Ch_off_prov & & & & & 1.000 & -.029 & -.014 \\
\hline Prov_Loans & & & & & & 1.000 & .665 \\
\hline Ch_off_Loans & & & & & & & 1.000 \\
\hline No of obs & 2445 & 2445 & 2445 & 2445 & 2445 & 2445 & 2445 \\
\hline
\end{tabular}
the interest expense to total assets, ROE is the return on equity, LnTA is the natural logarithm of total assets.

Table 2. Correlation Analysis

Pearson correlation analysis for all US banks for the period 2012-2017 are presented in this table. The dependent variable is CAR Tier1: capital adequacy ratio-Tier 1. Independent variables presented here are: ROA: Return on assets, Nimy: net interest margin, Loss is an indicator variable that takes the value of 1 if the financial institution has losses during a specific year and 0 otherwise, charge_off_Prov is the credit loss provision to net charge off, charge_off_loans: net charge off to loans, Prov_Loans: loss allowance to loans.

Table 3. Regression Analysis

\begin{tabular}{lcccc}
\hline Variable & Coefficient & Std error & t-stat & significance \\
\hline Ch_off_prov & .000 & .000 & 2.359 & .018 \\
Prov_Loans & .017 & .001 & 13.007 & .000 \\
Ch_off_Loans & -.007 & .002 & -4.017 & .000 \\
Loans_Dep & 0.000 & .000 & -.233 & .815 \\
IntExp_TA & .011 & .367 & .029 & .977 \\
ROE & .098 & .009 & 10.454 & .000 \\
LnTA & -.007 & .001 & -10.316 & .000 \\
Intercept & .219 & .010 & 20.961 & .000 \\
\hline F-value & 67.800 & & .000 \\
Rsquared & $16.10 \%$ & & & \\
Number of Obs & 2445 & & & \\
\hline
\end{tabular}

Multivariate regression analysis results for all US banks for the period 2012-2017 are presented in this table. The dependent variable is CAR_Tier1: capital adequacy ratio-Tier 1. Independent variables are: charge_off_Prov is the credit loss provision to net charge off, Prov_Loans: loss allowance to loans, charge_off_loans: net charge off to loans, Loans_Dep: net loans and leases to deposits, IntExp_TA is the interest expense to total assets, ROE is the return on equity, LnTA is the natural logarithm of total assets. 
Regarding overall results, the F-value of the model is 67.8, which is significant with a p-value 0.000. Results indicated that the explanatory variables affect CARs. Also, the adjusted R-squared is $16.1 \%$, which implies that the model's explanatory variables explain $16.1 \%$ in the variability of the dependent variable CAR_Tier1. Specifically, results indicate that five out of the six independent variables used in the model are statistically significant. These are Ch_off_loans, Prov_loans, Ch_off_prof, ROE and LnTA.

\subsubsection{Reduced Model with Loss as the only Explanatory Variable}

In Table 4 we present results on the relationship between capital adequacy (CAR_Tier1) and only one profitability measure, namely loss, beyond financial variables for all US National financial institutions over the period 2012-2017.

Regression model used:

$$
\begin{aligned}
\text { CAR }_{\text {Tier } 1}= & c_{0}+c_{3} * \text { Loss }+c_{4} * \text { ch }_{\text {off }} \text { prov } \\
& +c_{5} * \text { Prov }_{\text {Loans }} \\
& +c_{6} \text { ch }_{\text {offloans }} c_{7} * \text { Loans }_{\text {dep }}+c_{8} * \operatorname{IntExp}_{T A} \\
& +c_{9} * \text { ROE }+c_{10} * \text { LnTA }+e .
\end{aligned}
$$

Table 4. Regression Analysis results with Loss variable only as profitability measure

\begin{tabular}{lcccc}
\hline Variable & Coefficient & Std error & t-stat & significance \\
\hline Loss & -.006 & .008 & -.715 & .474 \\
Ch_off_prov & .000 & .000 & 2.373 & .018 \\
Prov_Loans & .017 & .001 & 13.023 & .000 \\
Ch_off_Loans & -.007 & .002 & -3.894 & .000 \\
Loans_Dep & 0.000 & .000 & -.227 & .821 \\
IntExp_TA & .026 & .368 & .071 & .943 \\
ROE & .094 & .011 & 8.918 & .000 \\
LnTA & -.007 & .001 & -10.336 & .000 \\
Intercept & .220 & .011 & 20.871 & .000 \\
F-value & 59.370 & & & .000 \\
Rsquared & $16.00 \%$ & & & \\
Number of Obs & 2445 & & & \\
\hline
\end{tabular}

Multivariate regression analysis results for all US banks for the period 2012-2017 are presented. The dependent variable is CAR_Tier1: capital adequacy ratio-Tier 1 . Independent variables are: Loss is an indicator variable that takes the value of 1 if the financial institution has losses during a specific year and 0 otherwise, charge_off_Prov is the credit loss provision to net charge off, Prov_Loans: loss allowance to loans, charge_off_loans: net charge off to loans, Loans_Dep: net loans and leases to deposits, IntExp_TA is the interest expense to total assets, ROE is the return on equity, LnTA is the natural logarithm of total assets.

Regarding overall results, the F-value of the model is 59.37 and significant with a p-value 0.000. Results indicate that the explanatory variables used in the model affect CARs. Also, the adjusted R-squared of this model is $16.0 \%$ which means that the variables used in the model explain $16.0 \%$ in the variation of the Tier1 CARs. Specifically, results show that the profitability variable Loss does not affect the capital adequacy of financial institutions, beyond the other financial variables. Results also show that five out of the six explanatory variables used in the model are statistically significant, namely, Ch_off_loans, Prov_loans, Ch_off_prof, ROE and LnTA.

\subsubsection{Reduced Model with Net interest Margin (nimy) as the Only Profitability Explanatory Variable}

In Table 5 we present results on the relationship between capital adequacy (CAR_Tier1) and only one profitability measure, namely net interest margin (nimy), beyond financial variables for all US National financial institutions.

Regression model used:

$$
\begin{aligned}
C A R_{\text {Tier } 1}= & c_{0}+c_{2} * \text { Nimy }+c_{4} * \text { ch }_{\text {off }} \text { prov } \\
& +c_{5} * \text { Prov }_{\text {Loans }} \\
& +c_{6} * \text { ch }_{\text {offloans }} c_{7} * \text { Loans }_{d e p}+c_{8} * \operatorname{IntExp}_{T A} \\
& +c_{9} * R O E+c_{10} * \text { LnTA }+e .
\end{aligned}
$$

Table 5. Regression Analysis results with Net interest margin (Nimy) only as profitability measure

\begin{tabular}{lcccc}
\hline Variable & Coefficient & Std error & t-stat & significance \\
\hline Nimy & -.765 & .066 & -11.570 & .000 \\
Ch_off_prov & .000 & .000 & 2.202 & .028 \\
Prov_Loans & .017 & .001 & 13.674 & .000 \\
Ch_off_Loans & .005 & .002 & 2.350 & .019 \\
Loans_Dep & 0.000 & .000 & .680 & .497 \\
IntExp_TA & .727 & .363 & 2.004 & .045 \\
ROE & .154 & .010 & 14.899 & .000 \\
LnTA & -.008 & .001 & -12.212 & .000 \\
Intercept & .251 & .011 & 23.817 & .000 \\
\hline F-value & 79.290 & & & .000 \\
Rsquared & $20.40 \%$ & & & \\
Number of Obs & 2445 & & & \\
\hline
\end{tabular}

In this table we present regression analysis results for all US financial institutions for the period 2012-2017. The dependent variable is CAR_Tier1: capital adequacy ratio-Tier 1 . Independent variables are: Nimy: net interest margin, charge_off_Prov is the credit loss provision to net charge off, Prov_Loans: loss allowance to loans, charge_off_loans: net charge off to loans, Loans_Dep: net loans and leases to deposits, IntExp_TA is the interest expense to total assets, ROE is the return on equity, LnTA is the natural logarithm of total assets.

Regarding overall model results, the F-value of the model is 79.29 and statistically significant with a p-value 0.000 . These results imply that the variables used in the model explain CARs. Moreover, the model's adjusted R-squared is $20.4 \%$, which means that the variables used in the model explain $20.4 \%$ in the variation of the Tier1 CARs. Results show that the profitability variable net interest margin affects negatively the capital adequacy of financial institutions, beyond the other financial variables. Results also show that four out of the six explanatory variables, beyond the control variable LnTA, used in the model are statistically significant, namely, Ch_off_loans, Prov_loans, Ch_off_prof, and ROE.

\subsubsection{Reduced Model with Return on Assets (ROA) as the Only Profitability Explanatory Variable}

In Table 6 we present results on the relationship between capital adequacy (CAR_Tier1) and only one profitability measure, namely $\mathrm{ROA}$, beyond financial variables for all US National financial institutions.

Regression model used:

$$
\begin{aligned}
C A R_{\text {Tier } 1}= & c_{0}+c_{1} * R O A+c_{4} * \text { ch }_{\text {off }} \text { prov } \\
& +c_{5} * \text { Prov }_{\text {Loans }} \\
& +c_{6} * \text { ch }_{\text {offloans }} c_{7} * \text { Loans }_{\text {dep }}+c_{8} * \operatorname{IntExp}_{\text {TA }} \\
& +c_{9} * \text { ROE }+c_{10} * \text { LnTA }+e .
\end{aligned}
$$


Table 6. Regression Analysis results with ROA only as profitability measure

\begin{tabular}{lcccc}
\hline Variable & Coefficient & Std error & t-stat & significance \\
\hline ROA & 1.375 & .076 & 18.011 & .000 \\
Ch_off_prov & .000 & .000 & 1.858 & .063 \\
Prov_Loans & .014 & .001 & 11.688 & .000 \\
Ch_off_Loans & -.010 & .002 & -5.668 & .000 \\
Loans_Dep & 0.000 & .000 & -.479 & .632 \\
IntExp_TA & .093 & .345 & .268 & .788 \\
ROE & -.061 & .012 & -4.893 & .000 \\
LnTA & -.006 & .001 & -9.811 & .000 \\
Intercept & .212 & .010 & 21.566 & .000 \\
\hline F-value & 107.900 & & & .000 \\
Rsquared & $25.90 \%$ & & & \\
Number of Obs & 2445 & & & \\
\hline
\end{tabular}

In this table we present regression analysis results for all US financial institutions for the period 2012-2017. The dependent variable is CAR_Tier1: capital adequacy ratio-Tier 1. Independent variables are: ROA: Return on assets, charge_off_Prov is the credit loss provision to net charge off, Prov_Loans: loss allowance to loans, charge_off_loans: net charge off to loans, Loans_Dep: net loans and leases to deposits, IntExp_TA is the interest expense to total assets, ROE is the return on equity, LnTA is the natural logarithm of total assets.

Regarding the overall performance of the model, the F-value is 107.9 and statistically significant with a p-value 0.000 . These results imply that the variables used in the model explain CARs Also, the model's adjusted R-squared is $25.9 \%$. Thus results indicate that the explanatory variables employed in the model explain $25.9 \%$ in the variability of the Tier1 CARs. Specifically, results show that the profitability variable ROA affects positively the capital adequacy of financial institutions, beyond the other financial variables. Results also show that five out of the six explanatory variables used in the model are statistically significant. These are Ch_off_loans, Prov_loans, Ch_off_prof, ROE and LnTA.

\subsubsection{Full Model with All Profitability Measures as Explanatory Variable}

In Table 7 we present results on the relationship between capital adequacy (CAR_Tier1) and all three profitability measures, beyond financial variables for all US National financial institutions.

Regression model used:

$$
\begin{aligned}
C A R_{\text {Tier } 1}= & c_{0}+c_{1} * \text { ROA }+c_{2} * \text { Nimy } \\
& +c_{3} * \text { Loss }+c_{4} * \text { ch }_{\text {off }} \text { prov } \\
& +c_{5} * \text { Prov }_{\text {Loans }} \\
& +c_{6} * \text { ch }_{\text {off }} c_{\text {loans }} c_{7} * \text { Loans }_{\text {dep }}+c_{8} * \operatorname{IntExp}_{\text {TA }} \\
& +c_{9} * \text { ROE }+c_{10} * \text { LnTA }+e .
\end{aligned}
$$

The F-value, which is an indicator of the overall performance of the model, is 108.5 and statistically significant with a p-value 0.000 . These results imply that the variables used in the model explain CARs. Moreover, the model's adjusted R-squared is 30.5\% which means that the variables used in the model explain $30.5 \%$ in the variation of the Tier1 CARs. Specifically, results show that all three profitability variables affect the capital adequacy of financial institutions, beyond the other financial variables. Results also show that five out of the six explanatory variables used in the model are statistically significant. These are Ch_off_loans, Prov_loans, Ch_off_prof, interest expense to total assets and LnTA.

Table 7. Regression Analysis - Full Model with all profitability measures

\begin{tabular}{lccccc}
\hline Variable & Coefficient & Std Error & t-value & Significance & VIF \\
\hline ROA & 1.398 & .074 & 18.872 & .000 & 2.082 \\
Nimy & -.786 & .062 & -12.710 & .000 & 2.246 \\
LOSS & -.017 & .007 & -2.451 & .014 & 1.360 \\
Ch_off_prov & .000 & .000 & 1.718 & .086 & 1.003 \\
Prov_Loans & .015 & .001 & 12.476 & .000 & 1.904 \\
Ch_off_Loans & .003 & .002 & 1.665 & .096 & 2.806 \\
Loans_Dep & 0.000 & .000 & .537 & .592 & 1.017 \\
IntExp_TA & .878 & .339 & 2.586 & .010 & 1.194 \\
ROE & -.017 & .014 & -1.256 & .209 & 2.607 \\
LnTA & -.007 & .001 & -12.087 & .000 & 1.087 \\
Intercept & .248 & .010 & 24.917 & .000 & \\
\hline F-value & 108.500 & & & .000 & \\
Rsquared & $30.50 \%$ & & & & \\
Number of Obs & 2445 & & & & \\
\hline
\end{tabular}

In this table we present regression analysis results for all US financial institutions for the period 2012-2017. The dependent variable is CAR_Tier1: capital adequacy ratio-Tier 1 . Independent variables are: ROA: Return on assets, Nimy: net interest margin, Loss is an indicator variable that takes the value of 1 if the financial institution has losses during a specific year and 0 otherwise, charge_off_Prov is the credit loss provision to net charge off, Prov_Loans: loss allowance to loans, charge_off_loans: net charge off to loans, Loans_Dep: net loans and leases to deposits, IntExp_TA is the interest expense to total assets, ROE is the return on equity, LnTA is the natural logarithm of total assets.

Finally, evidence presented in this table shows that the maximum value of the Variance Inflation Factors (VIFs) is 2.806, thus there is no multicollinearity. Econometric analysis states that multicollinearity will be a problem if VIFs are greater than 10 .

In summary, based on the aforementioned discussion, evidence shows that profitability measures do affect bank’s capital adequacy.

\section{Summary \& Conclusions}

In this study we examined whether profitability measures play an important role in explaining capital adequacy indicators of US banks. Our sample includes 2455 banks from 2012 till 2017. Our results indicated that financial institutions with greater return on assets are expected to have higher capital adequacy, whereas banks with losses and higher net interest margins are expected to have lower capital adequacy. So firms that have losses are expected to contribution negatively towards bank's capital adequacy. The same applies for banks with very high net interest margins, meaning that these banks take much higher risk. Evidence shows that when the profitability measures are excluded from the model, the model's Rsquared is $16.10 \%$ whereas when the three profitability variables are added in the model, the model's R-squared increases to $30.50 \%$, which is an overall improvement of $14.10 \%$. Evidence also shows that the biggest improvement is due to the inclusion of the ROA in the model. Specifically, when this variable was added in the 
model, the R-squared increased from $16.10 \%$ to $25.90 \%$, an overall increase of $9.80 \%$.

To sum up, the present evidence has practical implications and it should be of interest to bank executives and major stakeholders for decision making purposes and to regulators for policy purposes.

\section{References}

[1] Prachi, J., (2019), MSG Content, ManagementStudyGuide.com.

[2] ElBannan M., (2017), The Financial Crisis, Basel Accords and Bank Regulations: An Overview, International Journal of Accounting and Financial Reporting, Vol. 7, No. 2.

[3] Banking for International Settlements (2018), Annual Economic Report 2018, June, Published by BIS.

[4] Basel Committee on Banking Supervision (BCBS) (2010). Basel III: A global regulatory framework for more resilient banks and banking systems. Basel Committee on Banking Supervision, Basel.

[5] Basel Committee on Banking Supervision (BCBS) (2016), Guidance on the application of the Core Principles for Effective Banking Supervision to the regulation and supervision of institutions relevant to financial inclusion.

[6] Mili, M., J. Sahut, and H. Trimeche, (2014). Determinants of the Capital Adequacy Ratios of a Foreign Bank's Subsidiaries: The Role of the Interbank Market and Regulation of Multinational Banks: IPAG Business School.

[7] Aktas, R., Acikalin, S., Bakin, B., \& Celik, G. (2015). The Determinants of Banks' Capital Adequacy Ratio: Some Evidence from South Eastern European Countries. Journal of Economics and Behavioral Studies, 7(1), 79.
[8] Ahmad, R., Ariff, M., \& Skully, M. J. (2008). The determinants of bank capital ratios in a developing economy. Asia-Pacific financial markets, 15(3-4), 255-272.

[9] Estrella, A., Park, S., and Peristiani, S. (2000). Capital ratios as predictors of bank failure, FRBNY Economic Policy Review, 6 (2), 33-52. 20. Federal Reserve Bank (2003).

[10] Juca, M., A. Sousa, and A. Fishlow, (2012). Capital Structure Determinant's of North American Banks and the Compensation Executive Program: An Empirical Study on the Actual Systemic Crisis. International Journal of Business and Management, 7(17), 3-26.

[11] Schaek and Cihak. (2012). Banking Competition and Capital Ratios. European Financial Management, 18(5), 836-866.

[12] Santos, J. (2001) Bank capital regulation in contemporary banking theory: A review of the literature, Financial Markets, Institutions \& Instruments, December.

[13] Bateni L, H. Vakilifard and Asghari, (2014) The Influential Factors on Capital Adequacy Ratio in Iranian Banks, International Journal of Economics and Finance; Vol. 6, No. 11; 2014.

[14] Bokhari, I. H., Ali, S. M., and Sultan, K. (2012). Determinants of capital adequacy ratio in banking Sector: An Empirical analysis from Pakistan. Academy of Contemporary Research Journal, 2(1), $1-9$.

[15] Ho, S, and Su-Chu Hsu (2010), Leverage, performance and capital adequacy ratio in Taiwan's banking industry, Japan and the World Economy.

[16] Sivarama K, and A. Sukar, (2014). Capital ratios of US banks. International Journal of Business \& Economics Perspectives, 9(1).

[17] Shingjergii, A. and M. Hyseni, (2015). The determinants of capital adequacy ratio in Albanian banking system during 2007-2014, International Journal of Economics, Commerce and Management, $3(1), 1-10$. 